\title{
Preliminary Investigation for Engine Performance by Using Tire-Derived Pyrolysis Oil-Diesel Blended Fuels*
}

\author{
Islam M. ROFIQUL**, Hiroyuki HANIU***, Beg R. ALAM** \\ and Kazunori TAKAI*** \\ **Department of Mechanical Engineering \\ Rajshahi University of Engineering \& Technology, Rajshahi-6204, Bangladesh \\ E-mail:mrislam1985@yahoo.com \\ *** Depatment of mechanical Engineering \\ Kitami Institute of Technology, Kitami City, Hokkaido 090-8507, Japan \\ E-mail: harry@mail.kitami-it.ac.jp
}

\begin{abstract}
In the first phase of the present study, the pyrolysis oil derived from light automotive tire waste has been characterized including fuel properties, elemental analyses, FT-IR, ${ }^{1} \mathrm{H}-\mathrm{NMR}, \mathrm{GC}-\mathrm{MS}$ and distillation. The studies on the oil show that it can be used as liquid fuel with a gross calorific value (GCV) of $42.00 \mathrm{MJ} / \mathrm{kg}$ and empirical formula of $\mathrm{CH}_{1.27} \mathrm{O}_{0.025} \mathrm{~N}_{0.006}$. In the second phase of the investigation, the performance of a diesel engine was studied blending the pyrolysis oil with diesel fuel in different ratios. The experimental results show that the bsfc of pyrolysis oil-diesel blended fuels slightly increases and hence the brake thermal efficiency decreases compared to those of neat diesel. The pyrolysis oil-diesel blends show lower carbon monoxide (CO) emission but higher oxides of nitrogen $\left(\mathrm{NO}_{\mathrm{x}}\right)$ emissions than those of neat diesel. However, $\mathrm{NO}_{\mathrm{x}}$ emissions with pyrolysis oil-diesel blended fuels reduced when EGR was applied.
\end{abstract}

Key words: Light Automotive Tire Waste, Pyrolysis Oil, Engine Performance

\section{Introduction}

The energy crisis and environmental degradation are the main problems mankind is facing today. These problems owe their origin to a growing population, rapid industrialization and huge quantities of solid refuse, which are generated daily. By the year 2100 , the world population is expected to be in excess of 12 billion and it is estimated that the demand for energy will be increased by five times from what it is now. Also it is estimated that petroleum reserve of the world will be nearly exhausted by (2040) recent future. The increasing human population on the earth caused ever-increasing demand of energy. To alleviate part of our energy crisis and environmental degradation, it has become imperative to make use of appropriate technologies for the possible recovery of resources from non-conventional sources, like municipal and/or industrial organic wastes, refused plastics, used tires, etc. The disposal of these organic solid wastes from human activity is a growing environmental problem for modern society, especially in developing countries. The scrap tire is one of the very common and most important hazardous solid wastes all over the world.

It is reported that the annual estimated values of tire wastes generation are 15 million ton in the European Union, 2.5 in North America, 2.4 in UK, 1 in China, 0.5 in Japan, 0.17 in Korea, 0.09 in Bangladesh. This organic solid waste is non-biodegradable. One common 
way of disposal is landfilling. Landfilling for disposal of used tires is connected with some problems: it needs a considerable amount of space because the volume of tires cannot be compacted. Dumped scrap tire in massive stockpiles is one of the possible causes of ideal breeding grounds for disease carrying mosquitoes and other vermin with the aid of rain water, which is deposited in the free space of the tire wall. Also, landfilling is a potential danger because of the possibility of accidental fires with high emissions of hazardous gases. Moreover, different alternatives are often used for tire recycling such as retreading, reclaiming, incineration, grinding etc. with significant drawbacks and/or limitations ${ }^{(1)}$.

The pyrolysis of solid tire wastes has received increasing attention since the process conditions may be optimized to produce high energy density liquids, char and gases. In addition, the liquid products can be stored until required or readily transportation to where it can be most efficiently utilized. Tire pyrolysis liquids (a mixture of paraffins, olefins and aromatic compounds) have been found to have a high gross calorific value (GCV) of around 41-44 MJ/kg, which would encourage their use as replacements for conventional liquid fuels ${ }^{(1-8)}$. In addition to their use as fuels, the liquids have been shown to be a potential source of light aromatics such as benzene, toluene and xylene (BTX), which command a higher market value than the raw oils ${ }^{(1-3,7,9)}$. Pyrolytic char may be used as a solid fuel or as a precursor for activated carbon manufacture ${ }^{(1,7)}$. Some of the previous research groups ${ }^{(1,3,7}$, 9) studied the composition of evolved pyrolysis gas fraction and reported that it contains high concentrations of methane, ethane, butadiene and other hydrocarbon gases with a GCV of approximately $37 \mathrm{MJ} / \mathrm{m}^{3}$, sufficient to provide the energy required by the pyrolysis process.

The authors of the present paper have developed and operating a fixed-bed fire-tube heating pyrolysis unit to derive liquid fuels and chemicals from organic solid wastes. The details of the pyrolysis unit and characteristics of the solid tire wastes are presented elsewhere $^{(10,11,12)}$. In the present study, firstly the pyrolysis liquid products obtained from light automotive tire waste were characterized by elemental analysis and various chromatographic and spectroscopic techniques. In the second phase of the investigation, the performance of a diesel engine has been studied by using the pyrolysis oil-diesel blends. The pyrolytic oil was treated following decanting, centrifugation and filtration before preparing the blended mixture. The treated pyrolysis oil was mixed with diesel fuel as 5\%, $15 \%$ and $25 \%$ by volume of total mixture to produce three types of blends: P5\%-D, P15\%-D and P25\%-D, respectively. The prepared mixtures stored in glass bottles in laboratory environment for 24 hours and no phase separation was found by naked eye observation.

\section{Physical and chemical properties of the pyrolytic liquids}

\subsection{Standard methods followed for pyrolytic liquid analysis}

Pyrolytic liquids obtained under the maximum liquid yield conditions were well mixed and homogenized prior to analysis being made. Some physical properties of pyrolytic liquids: density, viscosity, flash point, pour point and GCV were determined by using the following standard methods: ASTM D189, ASTM D445, ASTM D92, ASTM D97 and ASTM D240 respectively. Elemental analysis (C, H, N and S) of liquids was determined with an elemental analyzer of model EA 1108, which followed the quantitative "dynamic flash combustion" method. The boiling point range distribution of hydrocarbons in the pyrolytic liquids was determined by using Thermo-gravimetric Analyzer (TGA) of model SHIMADZU TGA-50 according to ASTM D2887-89 standard test method. The sample $(15-20 \mathrm{mg})$ was heated from ambient temperature to $600^{\circ} \mathrm{C}$ at a heating rate of $10^{\circ} \mathrm{C} / \mathrm{min}$ in a high purity helium atmosphere at a flow rate of $100 \mathrm{ml} / \mathrm{min}$. The data obtained from TGA was used to evaluate the simulated distillation curves. The functional group compositions of the product liquids were analyzed by Fourier Transform InfraRed (FT-IR) spectroscopy. 
The FT-IR instrument of model PERKIN ELMER FTIR 2000 was used to produce the ir-spectra of the derived liquids. Identification of compounds in pyrolytic liquids was carried out by a gas chromatograph mass spectrometer of model GCMS-QP5000. The analysis was performed on a $60 \mathrm{~m} \times 0.32 \mathrm{~mm}$ capillary column coated with a $1 \mu \mathrm{m}$ film of DB-1. The oven temperature was programmed, $40^{\circ} \mathrm{C}$ hold for $10 \mathrm{~min}$ to $300^{\circ} \mathrm{C}$ at $5^{\circ} \mathrm{C} / \mathrm{min}$ hold for $10 \mathrm{~min}$. Compounds were identified by means of the NIST12 and NIST62 library of mass spectra and subsets HP G1033A. The ${ }^{1} \mathrm{H}$ NMR analyses of pyrolytic liquids were recorded at a frequency of $500 \mathrm{MHz}$ with an instrument of model JEOL A-500 using $\mathrm{CDCl}_{3}$ as solvent.

\subsection{Fuel properties of the pyrolytic liquids}

The pyrolytic liquids obtained from pyrolysis of automotive tire wastes, which are oily organic compounds, appears dark-brown-color with a strong acrid smell. Careful handling of the liquids is required since it reacts easily with human skins, leaving permanent yellowish brown marks and an acrid smell for a few days, which is difficult to remove by detergent. No phase separation was found to take place in the storage bottles. The fuel properties of the pyrolytic liquids in comparison to commercial automotive No.2 diesel, which is mostly consumed in Bangladesh, are shown in Table 1. The table shows that density of pyrolytic liquids was found higher than that of the commercial diesel fuel but lower than that of heavy fuel oil $\left(980 \mathrm{~kg} / \mathrm{m}^{3}\right.$ at $\left.20^{\circ} \mathrm{C}\right)$. The viscosity of liquid products from motorcycle tire wastes was slightly higher than that of the No.2 diesel but too much lower than that of heavy fuel oil $\left(200 \mathrm{cSt}\right.$ at $\left.50^{\circ} \mathrm{C}\right)$. Low viscosity of the liquids of $4.75 \mathrm{cSt}$ at $30^{\circ} \mathrm{C}$ is a favorable feature in the handling and transporting of the liquid. The flash point of a liquid fuel is the temperature at which the oil begins to evolve vapors in sufficient quantity to form a flammable mixture with air. The temperature is an indirect measure of volatility and serves as an indication of the fire hazards associated with storage and application of the fuel. The flash point of the tire-derived liquids was $\leq 32^{\circ} \mathrm{C}$. The flash point is low when compared

Table 1. Characteristics of the pyrolytic liquids in comparison to petroleum products

\begin{tabular}{lll}
\hline Analyses & $\begin{array}{l}\text { Tire-derived pyrolytic } \\
\text { liquids }\end{array}$ & $\begin{array}{l}\text { Commercial } \\
\text { automotive No.2 Diesel }\end{array}$ \\
\hline Elemental $(\mathrm{wt} \%)$ & & \\
$\mathrm{C}$ & 85.86 & $84-87$ \\
$\mathrm{H}$ & 9.15 & $12.80-15.70$ \\
$\mathrm{C} / \mathrm{H}$ & 9.38 & $5.35-6.80$ \\
$\mathrm{~N}$ & 0.65 & $65-3000 \mathrm{ppm}$ \\
$\mathrm{S}$ & 1.25 & $1100-7000 \mathrm{ppm}^{\text {; }}$ \\
Ash & 0.22 & 0.0 \\
$\mathrm{O}$ & 2.87 & 0.0 \\
$\mathrm{H} / \mathrm{C}$ molar ratio & 1.27 & $1.76-2.24$ \\
$\mathrm{O} / \mathrm{C}$ molar ratio & 0.025 & - \\
Empirical formula & $\mathrm{CH} \mathrm{H}_{1.27} \mathrm{O}_{0.025} \mathrm{~N}_{0.006}$ & - \\
Density $\left(\mathrm{kg} / \mathrm{m}^{3}\right)$ & 957 & $820-860$ \\
Viscosity $(\mathrm{cSt})$ & $4.75^{\#}$ & $2.0-4.5^{\circledR}$ \\
Flash point $\left({ }^{\circ} \mathrm{C}\right)$ & $\leq 32$ & $>55$ \\
Pour point $\left({ }^{\circ} \mathrm{C}\right)$ & -6 & $-40--30$ \\
Moisture $(\mathrm{wt} \%)$ & $\mathrm{N} / \mathrm{A}$ & $\approx 80 \mathrm{ppm}$ \\
$\mathrm{pH}$ value & 4.40 & - \\
$\mathrm{GCV}(\mathrm{MJ} / \mathrm{kg})$ & 42.00 & $44.00-46.00$ \\
\hline
\end{tabular}

Valid for legislation requirements of Bangladesh; $@ 30^{\circ} \mathrm{C} ;{ }^{\circledR} @ 40^{\circ} \mathrm{C}$ 
with petroleum-refined fuels; for example, kerosene has a required minimum flash point of $23^{\circ} \mathrm{C}$, diesel fuel of $55^{\circ} \mathrm{C}$ and light fuel oil $79^{\circ} \mathrm{C}$. The low flash points of the tire-derived liquids are not surprising since the product liquids represents un-refined liquids with a mixture of components having a wide distillation range. The pour point of the tire-derived liquids is comparatively low compared to the automotive diesel fuel but the laboratory experience of the authors of the present paper shows that it is not problematic even at $7^{\circ} \mathrm{C}$. The $\mathrm{pH}$ value of the pyrolytic liquids is $4 \sim 5$, which is in weak acidic nature. It is found that there is very little contamination of the liquids with metals $(\mathrm{V}, \mathrm{Mn}, \mathrm{Mg}, \mathrm{Ba}, \mathrm{Ni}, \mathrm{Ti}, \mathrm{Cu}, \mathrm{Cr}$, $\mathrm{Cd}, \mathrm{Co}, \mathrm{Fe}, \mathrm{Al}$, and $\mathrm{Zn})^{(8)}$, and does not contaminate with glass and PET plastic and/or other plastics $^{(10)}$. The $\mathrm{pH}$ value of soft drinks like Cola and Pepsi of Coca Cola company is 2.5 and they use PET plastic bottles for its storage and handlings. Thus, storage and handling of the liquids are little problematic in industrial usage in this regard. Cetane number is actually a measure of a fuel's ignition delay; the time period between the start of injection and start of combustion (ignition) of the fuel. In a particular diesel engine, higher cetane fuels will have shorter ignition delay periods than lower cetane fuels. The cetane number of the raw pyrolysis oil, P5\%-D, P15\%-D and P25\%-D is 40, 49, 47 and 44, respectively.

\subsection{Chemical composition of the liquid products}

Elemental analysis, $\mathrm{H} / \mathrm{C}$ and $\mathrm{O} / \mathrm{C}$ molar ratios, empirical formula and gross calorific values for the liquids are presented in Table 1 . The average chemical composition of the pyrolytic liquid has been analyzed as $\mathrm{CH}_{1.27} \mathrm{O}_{0.025} \mathrm{~N}_{0.006}$. Obviously, the product liquids contain a small amount of oxygen, with a higher $\mathrm{H} / \mathrm{C}$ ratio. The $\mathrm{H} / \mathrm{C}$ ratio of the pyrolytic liquids (Table 1) indicates that such oils are a mixture of aliphatic and aromatic compounds ${ }^{(2)}$. The $\mathrm{C} / \mathrm{H}$ ratio is somewhat higher than that found for petroleum derived fuels. The long chain diesel like structure attributes to high $\mathrm{C} / \mathrm{H}$ ratio as reflected by very high GCVs, comparable to fuel oil and diesel, as well as indicates the high miscibility with the diesel fuel as per like dissolves like principle. The nitrogen content is however, rather higher than the No.2 diesel but similar to a heavy fuel oil in the range of $0.3-0.5 \mathrm{wt} \%$. The sulphur content in the derived liquids is significantly high compared to the legislation requirements of commercial diesel fuel in Bangladesh (5000ppm or more) to safe environment. The important requirements for diesel fuel are its ignition quality, viscosity, water, sediment and sulfur contents. Therefore, the pyrolytic liquids require preliminary treatments such as decanting, centrifugation, filtration, desulphurization and hydrotreating to be used as fuels. The treated pyrolysis oil could be used directly as fuel oils or blended with diesel fuels, which will reduce the viscosity and, increase the $\mathrm{pH}$ value and flash point of the resulting blends. Consequently, the atomization will be improved, ensuring a complete burnout of the fuel ${ }^{(8)}$. Based on its fuel properties, tire-derived pyrolytic liquids may be considered a valuable component for use with automotive diesel fuels. Moreover, the liquids may be directly used as fuels for industrial furnaces, power plants and boilers.

The FT-IR is not the most appropriate analytical tool to determine saturated, aromatic and polar components. Nevertheless, it allows functional group analysis to reveal the chemical properties of the liquids. The FT-IR analysis for pyrolytic liquids derived from automotive tire waste have been carried out and the results obtained from the transmittance spectrums are presented in Table 2. The data shows therefore that the present liquids contain mainly aliphatic and aromatic compounds.

The ${ }^{1} \mathrm{H}$ NMR has been performed for the pyrolytic liquids and the hydrogen distribution obtained from the ${ }^{1} \mathrm{H}$ NMR spectrums is given in Table 3, indicating that no aliphatic carbon is still bound to oxygen (peaks in 3.3-4.5 ppm chemical shift range). Clearly, the main structure of the liquids seems to be aliphatic bonded to aliphatic only (0.4-1.8 ppm chemical shift range), and as a result the carbon aromaticity of the liquids is comparatively low. The 
Table 2. The FTIR functional groups and the indicated compounds of pyrolysis liquids

\begin{tabular}{lll}
\hline Frequency range $\left(\mathrm{cm}^{-1}\right)$ & Functional groups & Class of compounds \\
\hline $3100-3005$ & $\mathrm{C}=\mathrm{C}$ stretching & Alkenes \\
$3000-2800$ & C-H stretching & Alkanes \\
$1675-1605$ & $\mathrm{C}=$ C stretching & Alkenes \\
$1600-1545$ & Carbon-carbon stretching & Aromatic compounds \\
$1520-1115$ & C-H bending & Alkanes \\
$1020-845$ & C=C stretching & Alkenes \\
$810-660$ & C-H out-of-plane bending & Aromatic compounds \\
\hline
\end{tabular}

Table 3. ${ }^{1} \mathrm{H}$ NMR results for the pyrolytic liquids

\begin{tabular}{lll}
\hline Type of hydrogen & $\begin{array}{l}\text { Chemical shift } \\
(\mathrm{ppm})\end{array}$ & $\begin{array}{l}\text { Mol\% (\% of } \\
\text { total hydrogen) }\end{array}$ \\
\hline Aromatic & $9.0-6.5$ & 13.31 \\
Phenolic $(\mathrm{OH})$ or olefinic proton & $6.5-4.5$ & 9.74 \\
Aliphatic adjacent to oxygen/hydroxyl group & $4.5-3.3$ & -- \\
Aliphatic adjacent to aromatic/alkene group & $3.3-1.8$ & 17.55 \\
Other aliphatic (boded to aliphatic only) & $1.8-0.4$ & 59.40 \\
\hline
\end{tabular}

alkanes and long alkyl spectrums are probably largely derived from solid tire wastes.

Table 4 shows the tentative compounds assigned and their percentage area compared to the total area of the chromatogram, which gives an estimate for their relative concentration in the pyrolytic liquids. It can be seen that, tire pyrolysis liquids are a very complex mixture, containing many aliphatic and aromatic compounds with their total concentration of $49.54 \%$, and $16.65 \%$ respectively. The GC-MS results support well the results obtain from FT-IR [Table 2] and ${ }^{1} \mathrm{H}$ NMR [Table 3] analyses. The aliphatic compounds are mainly of alkane and alkene groups but the second is predominant (43.23\%). The aromatic compounds are only single ring alkyl aromatics. In addition to the main hydrocarbons, small percentage of nitrogen containing compound, 1-azido-2-methyl-benzene $\left(\mathrm{C}_{7} \mathrm{H}_{7} \mathrm{~N}_{3}\right)$; nitrogen, oxygen, and sulphur-containing compound, 5-methyl-6-phenyltetrahydro-1,3-oxazine-2-thione $\left(\mathrm{C}_{11} \mathrm{H}_{13} \mathrm{NOS}\right)$; and chlorine-containing compound, parachlorophenol $\left(\mathrm{C}_{6} \mathrm{H}_{5} \mathrm{ClO}\right)$; octanoyl-chloride $\left(\mathrm{C}_{8} \mathrm{H}_{15} \mathrm{ClO}\right)$ and 1-chloro-dodecane $\left(\mathrm{C}_{12} \mathrm{H}_{25} \mathrm{Cl}\right)$ were also identified. Other oxygen-containing compound in the form of acid such as 3-methyl-2-pentanoic acid is also present in the tire derived liquids. The most abundant compound present in the pyrolytic liquids is limonene whose total concentration is $29.54 \%$.

\subsection{Boiling point distribution of the pyrolytic liquids}

The boiling point distribution of hydrocarbons in pyrolytic liquids from pyrolysis of automotive tire wastes is presented in Fig. 1. For comparison purpose, the simulated distillation curves of commercial gasoline and diesel fuel are also presented in Fig. 1. The data shows that the pyrolytic liquids have a wide boiling point range. Pyrolytic liquids derived from tire waste contained about $40 \%$ gasoline fraction (boiling point range $<172^{\circ} \mathrm{C}$ ). It should be noted that the boiling point of pyrolytic liquids is lower than that of diesel fuel up to $92 \%$ by volume. The rest $8 \%$ has higher boiling point than that of diesel, which indicates the presence of some heavy hydrocarbon compounds of high boiling point. It can be concluded that the pyrolytic liquids from scrap tire wastes can be blended with the gasoline or diesel fuels after treatment such as desulphurization and fractional distillation. 
Table 4. Tentative GC/MS characterization of tire-derived pyrolytic liquids

\begin{tabular}{|c|c|c|}
\hline Retention time (min) & Tentative assignment & Peak area $(\%)$ \\
\hline 7.58 & 2-Methyl-1,3-butadiene & 1.39 \\
\hline 7.98 & 2-Methyl-2-butene & 0.29 \\
\hline 13.36 & Benzene & 0.13 \\
\hline 18.71 & Toluene & 6.03 \\
\hline 23.08 & 2-methyl-2-hepten-4-yne & 0.38 \\
\hline 23.57 & $p$-Xylene/1,4-Dimethyl-benzene & 3.14 \\
\hline 23.78 & $m$-Xylene/1,3-Dimethyl-benzene & 0.92 \\
\hline 23.82 & $o$-Xylene/1,2-Dimethyl-benzene & 1.24 \\
\hline 24.62 & 1-Azido-2-methyl-benzene & 3.45 \\
\hline 27.81 & 1,5-Dimethyl-1,5-cyclooctadiene & 4.85 \\
\hline 28.24 & (E,Z)-1,5-Cyclodecadiene & 2.14 \\
\hline 29.03 & 1,1-Dimethyl-2-(2,4-pentadienyl)-cyclopropane & 3.28 \\
\hline 29.15 & $\beta$-Myrcene & 2.28 \\
\hline 29.46 & (1S)-6,6-Dimethyl-2-methyl-bicyclo 3.1.1 heptane & 0.61 \\
\hline 29.54 & (Z)-3,7-Dimethyl-1,3,6-octatriene & 0.44 \\
\hline 29.62 & 3,7-Dimethyl-1,3,7-octatriene & 0.41 \\
\hline 29.66 & 2,6-Dimethyl-1,5,7-octatriene & 0.96 \\
\hline 30.11 & 2,5-Dimethyl-3-methylene-1,5-heptadiene & 0.81 \\
\hline 30.82 & Limonene & 21.76 \\
\hline 31.12 & Limonene & 1.52 \\
\hline 31.25 & Limonene & 6.26 \\
\hline 31.38 & (E)-3-Nonen-1-yne & 0.40 \\
\hline 31.61 & 1- propynyl-benzene & 0.96 \\
\hline 32.81 & 5-Methyl-6-phenyltetrahydro-1,3-oxazine-2-thione & 0.80 \\
\hline 32.89 & 2-Butenyl-benzene & 0.78 \\
\hline 35.28 & 1,3-Decadiyne & 0.41 \\
\hline 35.34 & 1,4,5,8-Tetrahydro-naphthalene & 0.12 \\
\hline 35.40 & 3-Undecene-1,5-diyne & 0.57 \\
\hline 36.55 & 3-Meththyl-2-pentenoic acid & 0.43 \\
\hline 36.70 & Parachlorophenol & 0.58 \\
\hline 37.80 & (Z)-3-Decen-1-yne & 0.21 \\
\hline 38.04 & (Z)-3-Dodecen-1-yne & 0.27 \\
\hline 39.29 & Octanoyl-chloride & 0.35 \\
\hline 39.46 & 1-Chloro-dodecane & 0.65 \\
\hline Total identified & & 69.00 \\
\hline
\end{tabular}

\subsection{Stability characteristics of the pyrolytic liquids (viscosity variation)}

The variations of viscosity of pyrolytic liquids over a time period for 12 months and over a temperature range of 30 to $100^{\circ} \mathrm{C}$ are presented in Table 5. It is interesting to note that the pyrolytic liquids when stored at room temperature and in the absence of air and light show almost no change in viscosity with time. Table 5 shows that the viscosity of the pyrolytic liquids decreases obviously with the increase of temperature. Over the same temperature range of $30-100^{\circ} \mathrm{C}$ the reduction rates of viscosity of the pyrolytic liquids, diesel fuels and a typical heating oils (fuel oil No. 2 ) are $4.2 \times 10^{-2}, \approx 5 \times 10^{-2}$ and $\approx 10 \times 10^{-2} \mathrm{cSt} /{ }^{\circ} \mathrm{C}$ respectively. It can be seen that there is a mild difference between the values of viscosity reduction rates of pyrolysis liquids and diesel fuels and hence the pyrolytic liquids would be less problematic for atomization when blending with diesel fuels. 


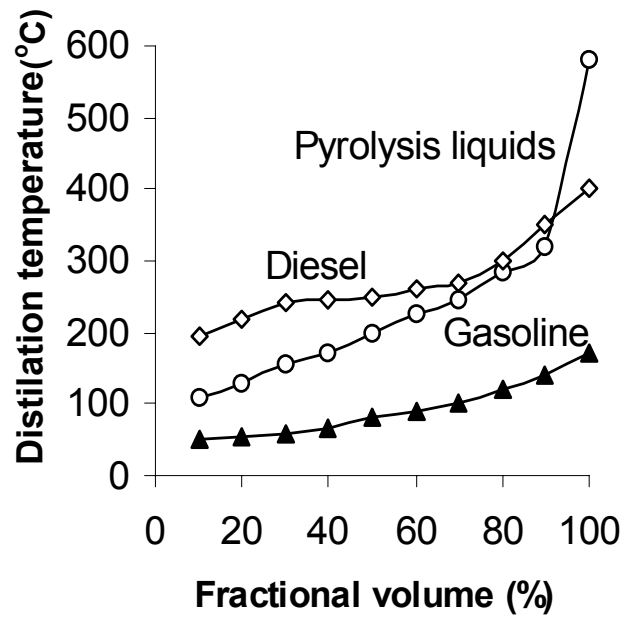

Fig. 1. Boiling point distribution of pyrolytic liquids compared to petroleum products

Table 5. Variation of viscosity over time and temperature

\begin{tabular}{ccccc}
\hline Time (Months) & Viscosity $(\mathrm{cSt})$ & & Temperature $\left({ }^{\circ} \mathrm{C}\right)$ & Viscosity $(\mathrm{cSt})$ \\
\hline 3 & 4.79 & & 30 & 4.75 \\
6 & 4.77 & & 50 & 3.86 \\
9 & 4.75 & & 75 & 2.70 \\
12 & 4.76 & & 100 & 1.75 \\
\hline
\end{tabular}

\section{Investigation for engine performance}

\subsection{Experimental set-up and procedure}

The engine used in the present investigation was a single cylinder, four strokes, water-cooled, naturally aspirated (NA), direct injection (DI) diesel engine. The technical data for the test engine are presented in Table 6. The experiment was conducted with conventional diesel fuel and pyrolysis oil-diesel blended fuels for comparison purposes. The engine speed was measured directly by the tachometer attached with the dynamometer. The outlet temperature of cooling water and exhaust gases were obtained directly from the thermometer attached to the corresponding passages. The injection timing was set at $13^{\circ}$ CATDC (after top dead center). The exhaust gases including smoke, $\mathrm{NO}_{\mathrm{x}}, \mathrm{CO}$ and $\mathrm{CO}_{2}$ were measured by a portable digital gas analyzer (IMR 1400). The data of exhaust emissions were taken in the exhaust pipe at a distance of $0.61 \mathrm{~m}$ from the engine. Before using the blended fuels, the standard operating conditions of the selected engine have been determined using neat diesel fuel. The filter smoke number readings were taken as $6,7,7.5$, 8 , etc. out of scale 10 .

Table 6. Technical data for the test engine

\begin{tabular}{ll}
\hline Items & Specifications \\
\hline Model & $\mathrm{S} 195$ \\
Type & Single cylinder \\
Bore $\times$ stroke & $95 \times 115 \mathrm{~mm}$ \\
Rated output & $9.8 \mathrm{~kW} @ 2000 \mathrm{rpm}$ \\
Compression ratio & $20: 1$ \\
Type of cooling & Water evaporative \\
Injection pressure & $13.5 \mathrm{MPa}$ \\
\hline
\end{tabular}




\subsection{Results and discussions}

\subsubsection{Standardizing the engine operating conditions}

Fig. 2 shows the variation of brake thermal efficiency with different engine speeds using neat diesel fuel. To optimize the engine speed, brake thermal efficiency versus engine speed curve is plotted. The brake thermal efficiency is defined as the actual brake work per cycle divided by the amount of fuel chemical energy as indicated by the fuel's lower heating value. It is seen from the figure that the brake thermal efficiency of the engine increases with an increase in engine speed up to $1000 \mathrm{rpm}$. This is due to the increase of fuel supply, which causes the increase of output power in the cycle. The brake thermal efficiency decreases with further increase of fuel supply consequently the increase of engine speed. The cause of decreasing brake thermal efficiency at an increased engine speed is insufficient amount of air supply, which causes improper burning of fuel in the combustion chamber. The engine speed of $1000 \mathrm{rpm}$ at which the brake thermal efficiency reaches to a maximum value is chosen as standard for all of experiments with pyrolysis oil-diesel blended fuels.
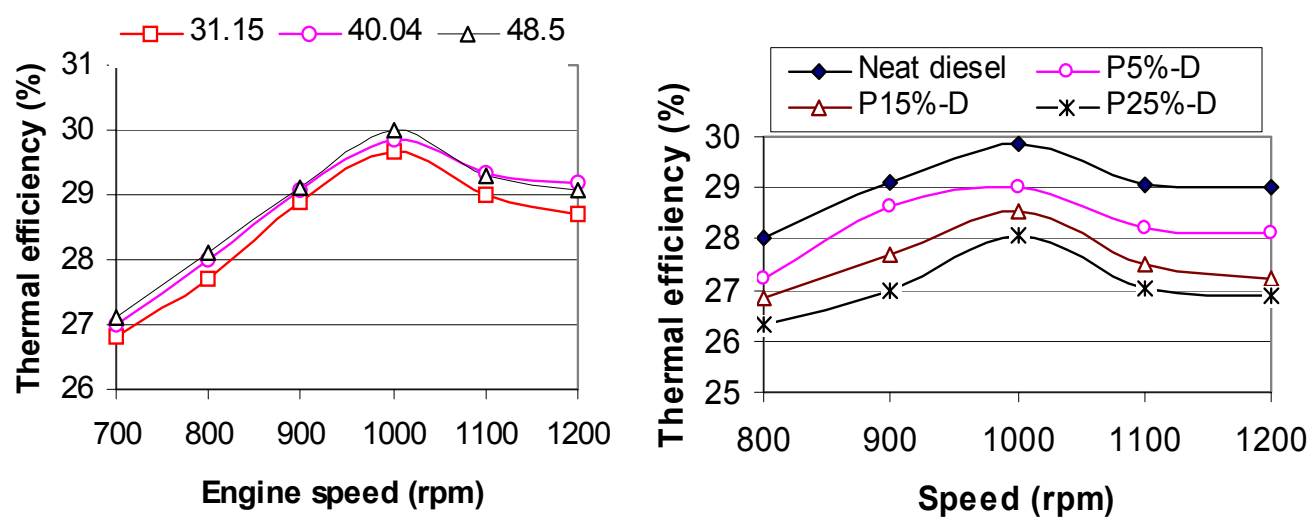

Fig. 2: Effect of engine speed on brake thermal efficiency

Fig. 3: Effect of engine speed on brake thermal efficiency for different blended fuels

\subsubsection{Effect of pyrolysis oil-diesel blends on brake thermal efficiency}

Brake thermal efficiency for the three selected pyrolysis oil-diesel blends compared to neat diesel fuel at different engine speed is presented in Fig. 3. The figure reveals that with the increase of engine speed the break thermal efficiency increases up to 1000rpm and then decreases for all of the blended fuels as of neat diesel. The thermal efficiency is reduced with the increase of blending percentage of the pyrolysis oil. This may be due to the low lower heating value and higher viscosity of the pyrolysis oil, which corresponds to slightly poor spray quality of the blended fuels.

\subsubsection{Effect of pyrolysis oil-diesel blends on brake specific fuel consumption}

The brake specific fuel consumption (bsfc) with respect to engine load and engine speed for three different pyrolysis oil-diesel blends compared to neat diesel are presented in Figs. 4 and 5, respectively. It is seen from the figures that although the blended fuels maintain a similar trend to the neat diesel, the value of bsfc for the blended fuels is higher compared to that of neat diesel for both of the entire engine load and engine speed ranges. This is due to the fact of little bit improper combustion (after burning) resulting from the slightly higher viscosity and low lower heating value of the pyrolysis oil than those of diesel fuel. 


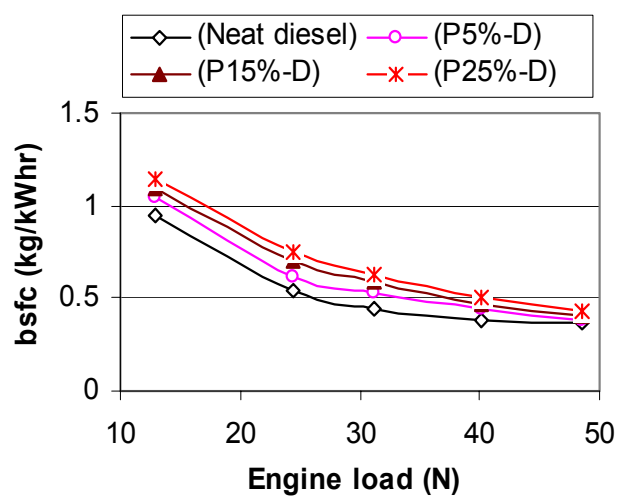

Fig. 4: Variation in brake specific fuel consumption at different load

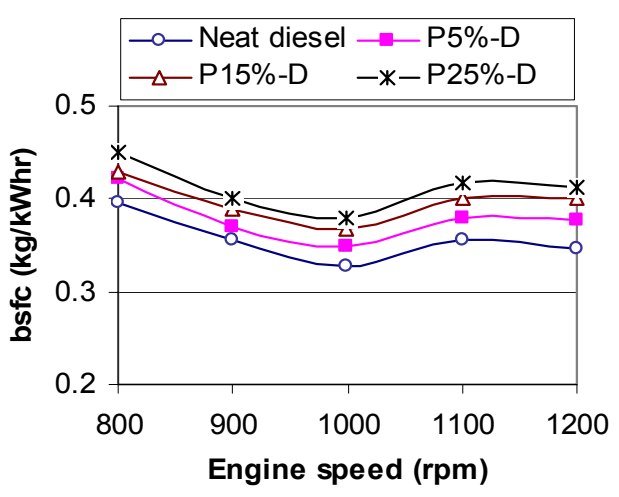

Fig. 5: Variation of bsfc at different speed

\subsubsection{Effect of pyrolysis oil-diesel blends on engine emissions}

The exhaust gas emissions data showed that smoke and $\mathrm{CO}_{2}$ emissions obviously increased with increasing engine load for both of pyrolysis oil-diesel blended fuels and neat diesel but less significant differences were found between these two types of fuel operations. Smoke is nothing but solid soot particles suspended in exhaust gas. The variation of smoke emission for different blends with engine load is presented in Fig. 6. From the figure it can be noticed that the smoke emission is higher for P5\%-D, P15\%-D and P25\%-D compared to neat diesel. Higher smoke values may be due to unburned and partially reacted hydrocarbons as well as sulfur compounds and bound water present in the pyrolysis oil-diesel blended fuels.

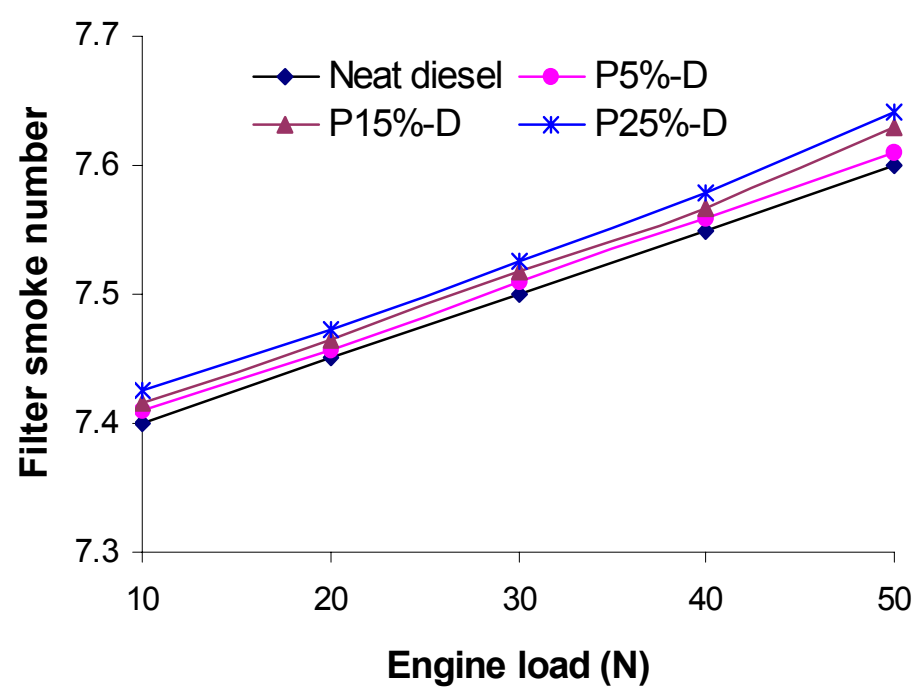

Fig. 6: Variation of smoke emissions with engine load

The significant differences were found in $\mathrm{CO}$ and $\mathrm{NO}_{\mathrm{x}}$ emissions. The $\mathrm{CO}$ and $\mathrm{NO}_{\mathrm{x}}$ emissions for the blended fuels compared to those of neat diesel at different load conditions are presented in Figs. 7 and 8, respectively. The engine speed was set at 1000rpm (optimized earlier). The Figs. 7 and 8 show that $\mathrm{CO}$ emission decreases while $\mathrm{NO}_{\mathrm{x}}$ emission increases with the increase of volumetric percentage of pyrolysis oil to diesel fuel. This may be due to the small amount of oxygen content in the tire-derived pyrolysis oil (Table 1), 


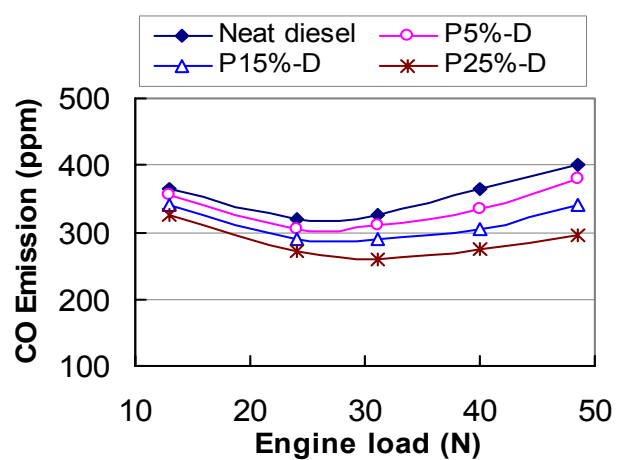

Fig. 7: $\mathrm{CO}$ emission at different load

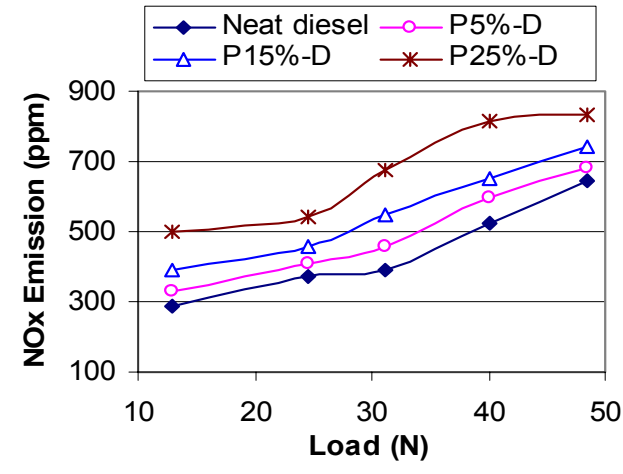

Fig. 8: $\mathrm{NO}_{\mathrm{x}}$ emission at different load

which favors comparatively complete combustion and hence lesser formation of CO. Lower $\mathrm{H} / \mathrm{C}$ molar ratio (Table 1) of the pyrolysis oil than that of diesel fuel supports this result. Due to low lower heating value of pyrolysis oil compared to diesel fuel, the mass of fuel burnt for a certain cycle is higher for pyrolyis oil-diesel blends than that of neat diesel for a particular engine load and engine speed. This is also cause of less $\mathrm{CO}$ and more $\mathrm{NO}_{\mathrm{x}}$ formation. It can be seen that the general tendency of $\mathrm{NO}_{\mathrm{x}}$ emissions is opposite to that for $\mathrm{CO}$ at the same engine operating conditions. The presence of oxygen in the pyrolysis oil helps to reduce $\mathrm{CO}$ while this may provide excess oxygen to produce higher $\mathrm{NO}_{\mathrm{x}}$ emissions. Besides, the Table 1 shows that the tire-derived pyrolysis oil contains higher percentage of $\mathrm{N}_{2}$ than that of present diesel fuel, which also favors $\mathrm{NO}_{\mathrm{x}}$ formation.

\subsubsection{Effect of EGR on pyrolysis oil-diesel blended fuels and neat diesel}

Diesel emission regulations continue to be tightened in many countries, necessitating diesel engines with the least possible emissions. Exhaust gas recirculation (EGR) is one of the most effective methods for reducing the emissions of nitrogen oxides $\left(\mathrm{NO}_{\mathrm{x}}\right)$ from diesel engines and has already been used to mass-produced engines. In order to meet the global steps for mitigation of future energy crisis as well as emission standards, it is crucial to use EGR for diesel engine operations with the present pyrolysis oil-diesel blended fuels.

The schematic diagram of the EGR system is presented in Fig. 9. The calibrated flow control valve controlled the EGR rates in volume percentage of fresh air. The pressure of the exhaust gas and in the intake manifold during suction stroke is slightly higher and lower than that of atmospheric, respectively. Fresh air inter into the intake manifold during suction stroke of the engine through an air drum, which is equipped with an orifice meter to measure volume flow rate. Varying the opening of the flow control valve varied EGR rate. When both the EGR valve and air drum are opened to the intake manifold, less amount of fresh air is induced that is equivalent to the volume of exhaust. The exhaust gas temperature at point of flow control valve was about $150^{\circ} \mathrm{C}$ for the standard engine operating conditions.

It is seen from Fig. 8 that the $\mathrm{NO}_{\mathrm{x}}$ emission for $\mathrm{P} 25 \%$-D blended fuel is significantly higher than that of neat diesel fuel. To reduce $\mathrm{NO}_{\mathrm{x}}$ emission the technique of EGR was taken into consideration for the present investigation. The engine operating condition was a constant speed of $1000 \mathrm{rpm}$ with a load of $40 \mathrm{~N}$. The Figs. 10 and 11 show the effect of EGR rates on $\mathrm{NO}_{\mathrm{x}}$ and $\mathrm{CO}$ emissions respectively. It can be seen from the Fig. 10 that with the increase in EGR rate, $\mathrm{NO}_{\mathrm{x}}$ emission decreases for both neat diesel and blended fuels. This may be for the reason that the specific heat of $\mathrm{CO}_{2}$ and $\mathrm{H}_{2} \mathrm{O}$ in the exhaust gases is higher than that of other gas components. When the engine works with EGR, the concentrations of $\mathrm{CO}_{2}$ and $\mathrm{H}_{2} \mathrm{O}$ in the engine cylinder become higher. As a result the heat capacity of $\mathrm{CO}_{2}$ and $\mathrm{H}_{2} \mathrm{O}$ reaches to a sufficiently higher value, which may be responsible for lower $\mathrm{NO}_{\mathrm{x}}$ production. 


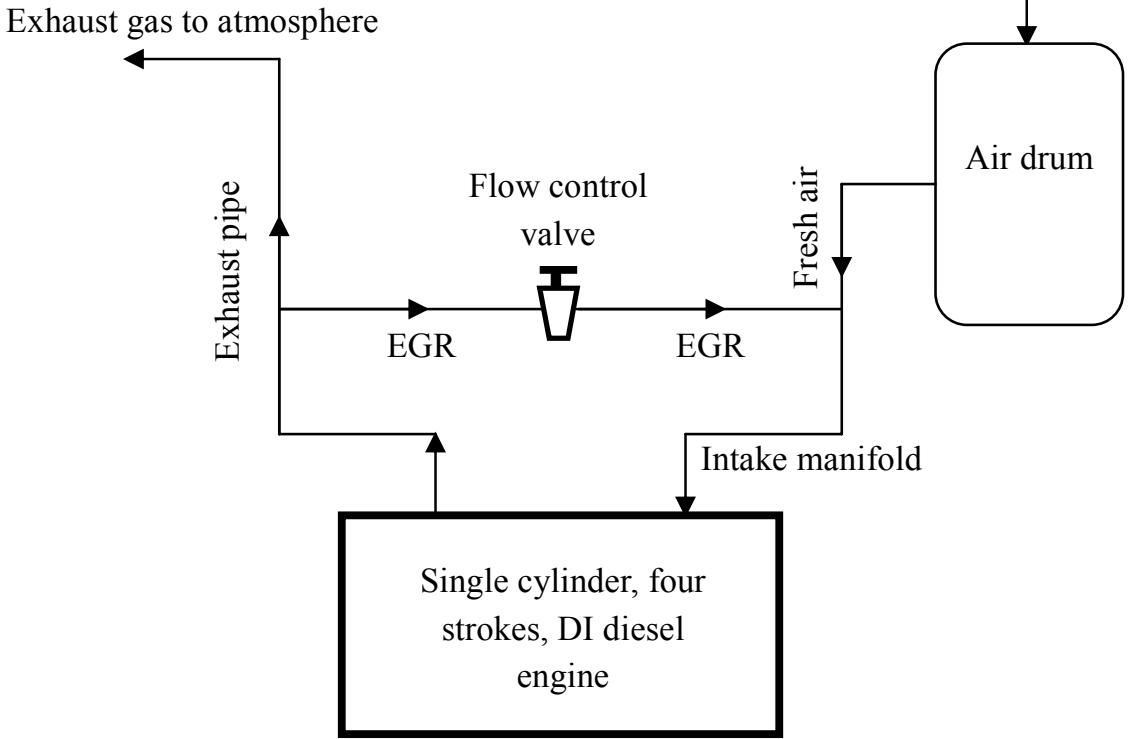

Fig. 9: Schematic diagram of the EGR system

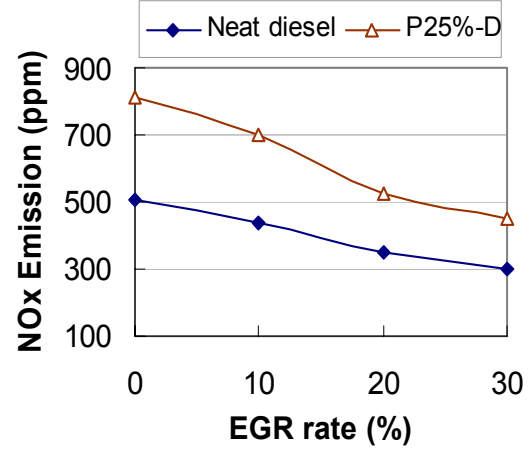

Fig. 10: Effect of EGR on $\mathrm{NO}_{\mathrm{x}}$ emissions

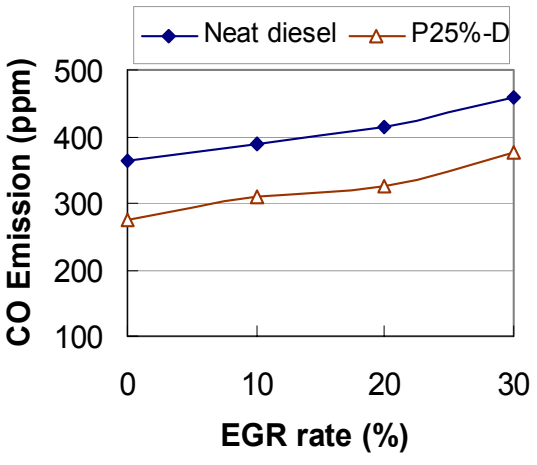

Fig. 11: Effect of EGR on CO emission

It can be seen from the Fig. 11 that $\mathrm{CO}$ emission increases with the increase in EGR rates for both neat diesel and blended fuels. It is to be noted that for P25\%-D blend, CO emission is significantly lower than that of neat diesel fuel for every EGR rate. Since pyrolysis oil presents some oxygen itself, this oxygen may help to reduce $\mathrm{CO}$ emission during combustion.

When the EGR is included the brake thermal efficiency of the engine reduces about $2-3 \%$ for both of blended fuel and neat diesel combustions. However, from the Figs. 7-8, $10-11$ it can be realized that using $\mathrm{P} 25 \%$-D blended fuel with $30 \%$ EGR, the engine emissions (both of $\mathrm{CO}$ and $\mathrm{NO}_{\mathrm{x}}$ ) can be maintained within the range of engine operations with neat diesel.

\subsubsection{Effect of pyrolysis oil-diesel blends on exhaust gas temperature}

Figs. 12 and 13 show the exhaust temperature for different pyrolysis oil-diesel blends with respect to brake power and engine speed respectively. The figures show that the exhaust gas temperature obviously increases with the increase in both of engine load and speed, and with the increase of volumetric percentage of pyrolysis oil in the blends.

After burning is the possible cause of higher exhaust gas temperature, which may be 
the results of slightly higher viscosity and presence of small amount of heavy compounds of high boiling points $\left(\mathrm{bp}>350^{\circ} \mathrm{C}\right)$ in the pyrolytic oil. The higher $\mathrm{NO}_{\mathrm{x}}$ formation without EGR also supports the result of higher exhaust gas temperature.

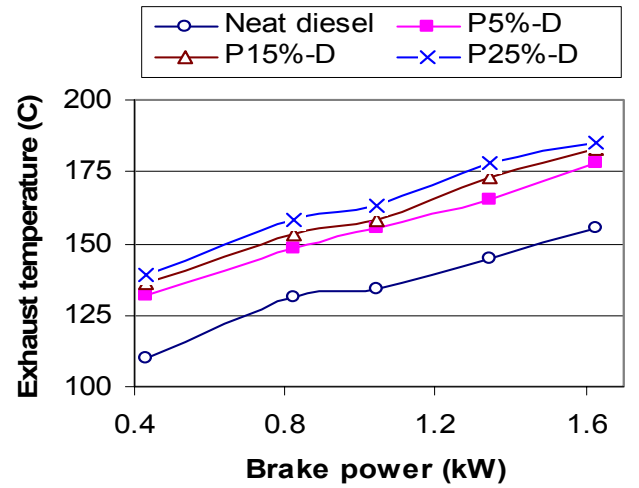

Fig. 12: Exhaust gas temperature for different brake power

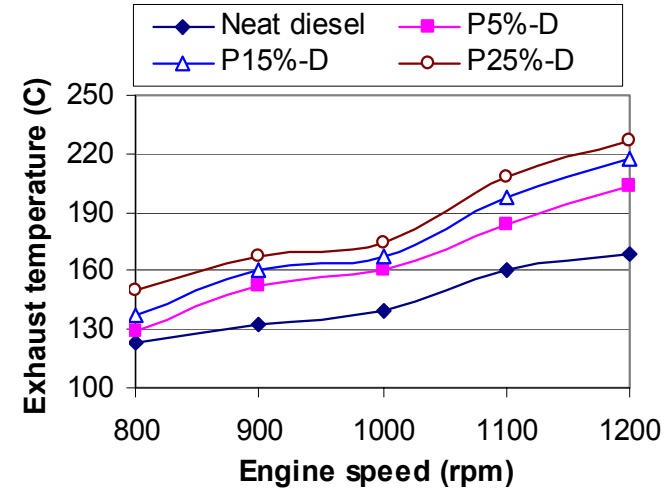

Fig. 13: Exhaust gas temperature for different speed

\subsubsection{Variation of heat release rate with crank angle}

Fig. 14 shows the heat release pattern of the neat diesel and pyrolysis oil-diesel blended fuels operation at the standard engine operating condition. The first stage is from the start of ignition to the point where the heat release rate drops and this is due to the ignition of fuel air mixture prepared during the delay period. The second stage starts from the end of the first stage to the end of combustion. The combustion duration increases with P15\%-D and P25\%-D. This is due to the higher quantity of fuel injected and low mixture preparation rates since $\mathrm{P} 15 \%-\mathrm{D}$ and $\mathrm{P} 25 \%$-D have longer ignition delay. The maximum rate of heat release for neat diesel is the highest compared to $\mathrm{P} 15 \%-\mathrm{D}$ and $\mathrm{P} 25 \%-\mathrm{D}$, as expected

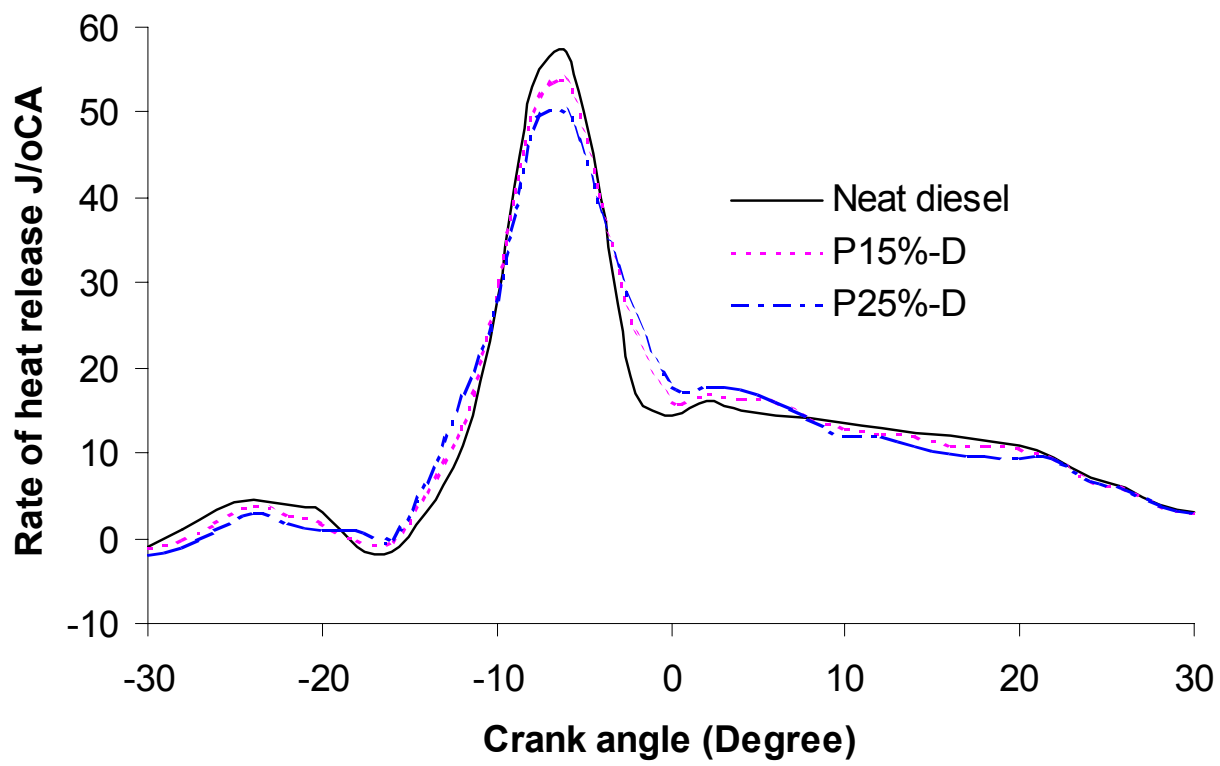

Fig. 14: Variation of heat release rate with crank angle

since fuels with longer ignition delay show higher rate of heat release at initial stage of combustion and increase in cylinder peak pressure. The maximum heat release is $57 \mathrm{~J} /{ }^{\circ} \mathrm{CA}$ 
for neat diesel. It can also be noticed that the maximum heat release is $53 \mathrm{~J} /{ }^{\circ} \mathrm{CA}$ for $\mathrm{P} 15 \%$-D and $50 \mathrm{~J} /{ }^{\circ} \mathrm{CA}$ for $\mathrm{P} 25 \%$-D. It can also be noticed that the diffusive combustion, the duration is longer and the heat released is lesser than neat diesel.

\subsubsection{Physical condition of the engine}

A continuous investigation has been conducted on the engine for three months. After completing the whole experiments, the engine was showing a little bit poor performance. To observe the physical conditions of the engine, it was disassembled and found that more contaminations were deposited on the cylinder head, valves and fuel injector. These worse conditions of the engine compared to those of neat diesel may be due to the presence of heavier compounds of high boiling points, aromatic compounds and particulate matters in the raw pyrolysis oils.

\section{Conclusions}

The aim of the present study was to investigate the suitability of pyrolysis oil as alternative for the diesel fuel in CI engine. The physical and chemical characterizations of the raw pyrolysis oil derived from light automotive tire waste have been carried out and the engine performance and emission tests were conducted with pyrolysis oil-diesel blended fuels in a CI engine. The results may be summarized as follows:

- The characterizations of the tire-derived pyrolytic oil show that density, viscosity, GCV, carbon and hydrogen contents are almost comparable to those of the commercial automotive diesel fuels but higher sulphur content and lower flash point are problematic.

- The pyrolytic liquids abundantly contain olefins, specially limonene and light aromatics, whose have higher market values as chemical feedstock than their use as fuels.

- The bsfc of pyrolysis oil-diesel blended fuels increases and hence the brake thermal efficiency decreases compared to those of neat diesel.

- $\mathrm{CO}$ emission reduces while $\mathrm{NO}_{\mathrm{x}}$ emission increases with the increase of volumetric percentage of pyrolysis oil in the blended fuels.

- $\mathrm{P} 25 \%$-D blended fuel with 30\% EGR shows the suitability of pyrolysis oil to be used as an alternative for diesel to mitigate the future fuel crisis.

- The fractional distillations and desulphurization or blending the raw pyrolysis oil with petroleum refinery stream are essential to be used as alternative for diesel fuel as well as to fulfill the present legislation requirements of diesel fuels.

\section{References}

(1) Rodriguez IM, Laresgoiti MF, Cabrero MA, Torres A, Chomon MJ, Caballero BM. Pyrolysis of scrap tires. Fuel Process Tech 2001;72:9-22. [and references therein]

(2) Laresgoiti MF, Caballero BM, De Marco I, Torres A, Cabrero MA and Chomon MJJ. Characterization of the liquid products obtained in tire pyrolysis. J. Anal. Appl. Pyrolysis 2004;71:917-934.

(3) Gonzalez JF, Encinar JM, Canito JL, Rodriguez JJ. Pyrolysis of automotive tire waste. Influence of operating variables and kinetic study. J. Anal. Appl. Pyrolysis 2001;58-59:667-683 [and references therein].

(4) Diez C, Martinez O, Calvo LF, Cara J, Moran A. Pyrolysis of tires. Influence of the final temperature of the process on emissions and the calorific value of the products recovered. Waste Management 2004;24:463-469.

(5) Dai X, Yin X, Wu C, Zhang W, Chen Y. Pyrolysis of waste tires in a circulating 
fluidized-bed reactor. Energy 2001;26:385-99.

(6) Pakdel H, Pantea DM, Roy C. Production of $d l$-limonene by vacuum pyrolysis of used tires. J. Anal. Appl. Pyrolysis 2001;57:91-107.

(7) Cunliffe AM, Williams PT. Composition of oils derived from the batch pyrolysis of tires. J Anal Appl Pyrol 1998;44:131-152. [and references therein]

(8) Roy C, Chaala A, Darmstadt H. Vacuum pyrolysis of used tires End-used for oil and carbon black products. J. Anal. Appl. Pyrolysis 1999;51:201-21.

(9) Williams PT, Brindle AJ. Aromatic chemicals from the catalytic pyrolysis of scrap tires. J Anal Appl Pyrolysis 2003;67:143-164.

(10) Islam MR, Haniu H, Rofiqul ABM. Limonene-rich liquids from pyrolysis of heavy automotive tire wastes. Journal of Environment and Engineering 2007;2(4):681-695.

(11) Islam MR, Tushar MSHK, Haniu H. Production of liquid fuels and chemicals from pyrolysis of Bangladeshi bicycle/rickshaw tire wastes. J Anal Appl Pyrolysis 2008;82:96-109.

(12) Islam, MR, Haniu, H and Fardoushi, J. Pyrolysis kinetics behavior of solid tire wastes available in Bangladesh. Waste Management 2008;29:668-677. 